\title{
Designing for the Power to Act Together in organisations : the case of a business process
}

Concevoir pour le pouvoir d'agir ensemble au sein des organisations : le cas d'un processus commercial

Céline Poret, Viviane Folcher, Florence Motté and Yvon Haradji

\section{OpenEdition}

\section{Journals}

Electronic version

URL: http://journals.openedition.org/activites/2917

DOI: $10.4000 /$ activites. 2917

ISSN: $1765-2723$

Publisher

ARPACT - Association Recherches et Pratiques sur les ACTivités

\section{Electronic reference}

Céline Poret, Viviane Folcher, Florence Motté and Yvon Haradji, « Designing for the Power to Act Together in organisations : the case of a business process », Activités [Online], 13-2 | 2016, Online since 15 October 2016, connection on 20 April 2019. URL : http://journals.openedition.org/ activites/2917; DOI : 10.4000/activites.2917

This text was automatically generated on 20 April 2019.

\section{c)}

Activités est mis à disposition selon les termes de la licence Creative Commons Attribution - Pas d'Utilisation Commerciale - Pas de Modification 4.0 International. 


\section{Designing for the Power to Act Together in organisations : the case of a business process}

Concevoir pour le pouvoir d'agir ensemble au sein des organisations : le cas d'un processus commercial

Céline Poret, Viviane Folcher, Florence Motté and Yvon Haradji

\section{EDITOR'S NOTE}

Article soumis le 02/02/2016, accepté le 30/06/2016

\section{Introduction}

1 The change in corporate status, from that of a public status where the objective is the service provided to the client, to a private status which has more to do with being part of a competitive world, is always a major challenge for service relationships and the actors involved. Be it in the undertaking sector (Trompette \& Boissin, 2000), La Poste (FlageulCaroly, 2001) or France Telecom (Hochereau, 2004), these changes within public companies have always led to rupture for actors who see their professions having to integrate commercial objectives that are inconsistent with the objectives of public service, thus causing them to develop strategies to cope with conflicting logics (Bernard, 2005 ; Buscatto, 2002; Calderon, 2006; Cihuelo, 2010 ; Flageul-Caroly, 2001). When the energy market opened up to competition, Electricité de France (EDF) underwent a profound upheaval which led, in particular, to changes in organisation and service relationships, impacting the jobs, tools and organisations concerned. It was within this framework that EDF's R\&D department initiated a technological research programme called "Engineering for the service relationship", the aim of which was to develop highquality service relationships by acting on tools and corporate organisation in order to 
help with individual and collective activity and to improve working conditions. The request at the origin of this research is part of this research programme and relates to understanding the dynamic of a collective activity which cuts across the organisation and whose objective is to provide the service to clients. This understanding of collective activity - known as "cross-functional and transactional collective activity" (Motté \& Haradji, 2010 ; Poret, 2015) - must make it possible to contribute towards the development of tools, methods of organisation and professions with a view to turning the corner into a competitive world by improving customer satisfaction, employee working conditions and company efficiency.

2 After presenting the cross-functional paradigm - in which companies that henceforth consider their performance in terms of their cross-functional operational processes are embedded - we argue that despite this change in paradigm, said cross-functionality is not really effective. This lack of true cross-functionality results from limited consideration of the cross-functional and transactional collective activity which must exist and which must go beyond a company's standard boundaries. We argue that designing for this collective activity means designing for the Power to Act Together (Poret, 2015), which in turn means thinking about the "Actor-Environment" relationship. We then set out the type of cross-functional and transactional collective activity that we have studied - EDF's commercial process for dealing with requests for dual-fuel installations - and our methodology for gathering and analysing data. We then describe the instruments built by the actors to serve this collective activity - cooperative transitional instruments (Poret, ibid) ; they enable continuity despite company fragmentation and constitute a support for true corporate cross-functionality. Finally, we suggest a design criterion (the continuity criterion) whose mobilisation during the course of development projects relating to the technical-organisational environment makes it possible to take into account the need to create a cross-functional and transactional collective activity and to construct and mobilise cooperative transitional instruments to serve said activity.

\section{A paradigm of corporate cross-functionality}

\subsection{A transformation of the economic environment}

3 The way companies are organised has undergone a change in paradigm, from one which until recently privileged verticality and job specialisation, to a paradigm favouring crossfunctionality (Poret, 2015) and interprofessional cooperation. In this regard, Zarifian (1995) and Detchessahar (2003) talk about the shift from a "paradigm of the separation of tasks and responsibilities" to a "paradigm establishing work cooperation". This change in paradigm was initiated by a transformation of the economic environment dating back to the late 1970's and early 1980's (Defelix, 1999 ; Du Tertre, 2013 ; Hammer \& Champy, 1993 ; Tarondeau, 2002; Veltz \& Zarifian, 1994; Watiez, 2002). Generally speaking, this transformation meant that companies had new organisational needs, because they were now required by clients, competition and change to become flexible (Greenan \& Mairesse, 2006 ; Hammer \& Champy, 1993 ; Roy \& Audet, 2002 ; Tarondeau, 2002 ; Watiez, 2002) and responsive (Askenazy, 2005), upon pain of not surviving within this ever-changing environment. 


\subsection{Conceptualizing performance in terms of building value for a client : the process, a new corporate cornerstone}

4 In order to meet these demands for flexibility and responsiveness, companies have transformed their organisation by redefining their performance using cross-functional operational processes. We have shifted from a company using a "flat" organisation to one that has a "fishbone" structure (Ségrestin, 2004). The general idea is that a company with a fishbone structure has "a horizontal line representing the course of its activity [which] cuts across vertical structures that provide support" (Ségrestin, ibid., p. 200). This bone symbolises the cross-functional process, defined as "coordinated sets of local activities which, through their conjunction, make it possible to produce value for the customer or an important element of internal operation" (Lorino, 2009). Here, the organisation is no longer conceptualised in line with a logic of job specialisation, as is the case with the "flat" vision, but in accordance with a logic of producing value for the customer.

This paradigmatic change has been the basis for various transformations within companies :

- the emergence of New Organisational Forms (NOF) such as networking organisations, management by projects, the development of employee polyvalence by compressing the stages that make up the cross-functional process into one single person (Hammer, 1990);

- the emergence of technical sublayers structurally designed around the notion of crossfunctional processes, such as Enterprise Resource Planning (ERP) (Mourlon \& Neyer, 2002) and workflow systems (Khoshafian \& Buckiewicz, 1998);

- the emergence of new managerial models such as Lean Management (Lasnier, 2007 ; Ughetto, 2012), quality management with implementation of ISO 9001, along with performance management and the introduction of related indicators (Derujinsky-Laguecir, Kern \& Lorino, 2011).

6 However, despite these transformations, cross-functionality does not appear to be totally effective, impacting company performance, customer satisfaction and employee job satisfaction. For example, as customers using a service we have all experienced this lack of cross-functionality, having to constantly repeat to each person we speak to the reasons for our call, what has been said and done since our previous call, hanging up without having obtained an answer and without having made any progress with our request ... and then having to go through it all again during our next attempt. As employees involved in producing a service, people in direct contact with customers are often considered to be responsible for the quality of that service, with the weight of the entire company on their shoulders (Motté \& Haradji, 2010). This role of interfacing between the company and its customers can be complicated when the employees concerned do not have the resources needed to deal with customers' inquiries. The reasons for this lack of true cross-functionality, despite changes to a company's technical, organisational and managerial environment, as they relate to the notion of cross-functional processes, lie in an assumption that the process will be equal to the sum of the individual contributions that comprise it. Yet far more than that, the process constitutes a collective activity that involves cooperation between all of the actors concerned. 


\subsection{The process : a cross-functional and transactional collective activity}

7 Ergonomics (Arnoud, 2013 ; Motté \& Haradji, 2010 ; Petit, 2005) and management (Lorino, 2009, 2013 ; Lorino \& Peyrolle, 2005 ; Lorino \& Tricard, 2012) have gradually highlighted and conceptualized this new form of activity which takes place at the heart of this crossfunctional process. Whether we refer to this activity as "cross-functional collective activity" (Motté \& Haradji, 2010) or "joint collective activity" (Lorino, 2009, 2013 ; Lorino \& Peyrolle, 2005), it remains the same type of activity taking place across the company as a whole. It is a collective activity "where different actors are required to do different things in a coordinated manner in order to produce a result through the complementarity of their involvement" (Lorino \& Peyrolle, 2005, p. 224). This form of collective activity contrasts with that which is more conventionally apprehended within communities of practice (Lave \& Wenger, 1991) where "the same type of work is carried out by all members of a group" (Lorino \& Peyrolle, 2005, p. 223). More accurately, this collective activity is both cross-functional and transactional :

- it is transactional ${ }^{1}$ in as much as the actors concerned must make a transaction with the world : the production of value for the customer. Said transaction, "like the pieces of a jigsaw puzzle, only makes sense when their respective actions are brought together, in terms of their cooperation" (Lorino, 2009 ; Lorino \& Peyrolle, 2005) ;

- it is cross-functional in as much as in order to reach the final objective of the process - the transaction with the world - the various actors involved in each of its constituent activities must cooperate by articulating their respective contributions across the organisation as a whole.

It is characterised by four dimensions (Poret, 2015) :

- the interdependency between the activities of the various actors involved: the result of actor 1's activity constitutes the starting point for actor 2's activity, the results of which will in turn constitute the starting point for actor 3 , and so on ;

- the process as mesh analysis: mesh analysis of this new form of collective activity is constituted by the process, because it is within this process - designed to create value for a customer - that this collective activity is deployed and that the different actors involved are interdependent ;

- an interdependency spread over time: the interdependency of the collective activity's various constituent activities is a staggered interdependency. It is distributed on a temporal basis, because the actors do not intervene at the same time but one after the other, and on a spatial basis because they belong to different departments/entities and are therefore not located in the same place;

- the technical-organisational system as a coordination point: the cooperation between actors has to take place within the technical-organisational system, because the actors do not share the same space or time. We use the term "technical-organisational system" to talk about a divided form of organisation which fragments collective activity, and about a technical system which is at the heart of this organisation, constituted in particular by Enterprise Resource Planning (ERP).

9 Examination of this form of collective activity shows that a company's cross-functional vision relates to the need for cross-functional cooperation between the actors of a given process. Boreham, Samurçay \& Fischer (2002) thus showcase "Work Process Knowledge" 
(WPK), which they define as a new type of knowledge that actors working together within a given process must have at their disposal if they wish to cooperate within a flexible organisation. They believe it is a question of being aware of the interdependencies between the activities of the various functions involved in a given process and of understanding the specificities of each one whilst at the same time understanding how the service is produced at a systemic level. In this respect, Nascimento (2009) talks about a need for "everyone to be present in each individual's work" (p. 84).

\section{Anchoring cross-functionality at the heart of organisations : designing for the Power to Act Together}

\subsection{From non-consideration to limited consideration of cross- functional and transactional collective activity}

As things currently stand, companies have varying views of this collective activity.

11 More often than not it is ignored, cross-functionality only being considered through the prism of technological sublayers which are supposed to anchor it at the heart of organisations, such as Enterprise Resource Planning (ERP). The dominant assumption behind their success would seem to be that they simply need to be deployed in order for cross-functionality to be effective. So if each actor involved in the process properly completes his share of the work, then thanks to the integrated dimension made possible by these technological sublayers, the whole would equal the sum of its parts. This manner of considering cross-functionality ignores the fact that in order for the crossfunctionality to be effective, there must be cooperation between its actors.

The result of this collective activity being examined in ergonomics (Arnoud, 2013; Motté \& Haradji, 2010 ; Petit, 2005) and management (Lorino, 2009, 2013 ; Lorino \& Peyrolle, 2005 ; Lorino \& Tricard, 2012) has been that is has received greater consideration. When it is considered, the debate on practices employed by the actors involved in the same crossfunctional process is a recurrent possibility to encourage the emergence of preconditions for this type of collective activity (Arnoud, 2013 ; Arnoud \& Falzon, 2013, 2014 ; Lorino, 2009 ; Nascimento, 2009; Petit, 2005). The debate on practices allows actors to become aware of the interdependencies of their respective contributions. This awareness relates to the fact that they are part of a collective, the existence of which is sometimes unknown to them, and to the identification of the needs of the other actors taking part in the collective. They are then able to do whatever is required to meet said needs, i.e. to do things that are not directly pertinent to themselves or to their own contributions, but which are useful to other actors involved in the cross-functional and transactional undertaking. For example, Lorino \& Peyrolle (2005) have shown how the fact of debating on the practices of different actors involved in the same process - EDF-GDF's "green tariff" process - allowed sellers to make sense of a so-called "ghost" (nil) invoice, something they had never been able to do before. Whilst such an invoice is vital for accountants, the sellers did not see the point and so did not issue any. The debate on actors' practices made them aware of the need to issue and send such invoices to customers. The sellers thus integrated this accounting requirement into their own activity even though this gave no added value to their own contributions. 


\subsection{Designing for cross-functional and transactional collective activity means thinking about the "Actor-Environment" relationship}

13 Whilst awareness of interdependencies (made possible by debating on practices) creates the preconditions for cross-functional and transactional collective activity, it does not automatically guarantee that such activity will exist in reality, i.e. in the technical and organisational system in which it develops. The fact that the actors of the crossfunctional and transactional collective are aware of and have knowledge of everyone's needs will not enable them to intersect in real terms in a technical-organisational system that does not so allow. For example, let us imagine that Actor 1 is involved in stage A (in the front-office) and is aware of one of the needs of Actor 2 who is in charge of stage B (in the back-office). The latter needs to send a reference number that only Actor 1 can obtain from the customer. Actor 1 might have knowledge of this and go ahead and obtain the reference number from the customer, but if the technical-organisational device has not planned any space for such an exchange between Actor 1 and Actor 2, then this knowledge is useless. If the matter of transformation is only envisaged through transformation of the actors of the cross-functional and transactional collective, without systematically examining the issue of the transformation of the technical-organisational environment that constitutes the place of their coordination, then the approach to this collective activity is limited. Of course, transformation of the technical-organisational environment is not always necessary ; knowledge of the needs of the other actors of the cross-functional and transactional collective might resonate positively within this environment, making collective action possible. It is also possible that it finds no positive resonance and that it merely remains at a level of knowledge that is required for collective action but which is impossible to actually use in practice. Designing for crossfunctional and transactional collective activity thus means thinking about the question of transformation in relation to the "Actor-Environment" and not just in terms of the actors involved in the collective activity. Although this is true for all design projects, it is even more so here, in as much as the temporal and spatial distribution that characterises this collective activity gives a pivotal role to the technical-organisational environment.

\subsection{Designing for cross-functional and transactional collective activity : designing for the Power to Act Together}

14 If the debate on practices and the transformations it enables are not systematically considered in relation to the technical-organisational environment, there is a risk of only allowing the construction of Capacities to Act in the sense of Rabardel (2005a, 2005b), taken to be the operative resources available to the actors for acting in the world.

Within the conceptual framework of the Power to Act as used in this work (Rabardel, 2005a, 2005b), the distinction between Capacities to Act and Powers to Act demonstrates the difference between potential and actual. Capacities to Act fall on the side of potential and we have chosen to understand them as instruments, i.e. as operative resources that an actor builds in order to act in the world. They are not capacities which are given, but ones that result from development by and within the activity. Powers to Act, on the other hand, fall on the side of what is actual and depend on the circumstances and on the internal and external conditions of the subject's action. 

these capacities to act as "Capacities to Act Together" (Poret, 2015). If we want these Capacities to Act Together to be effectively useable in context, i.e. that they become "Powers to Act Together" (Poret, ibid), then we must consider the conditions under which they are effectively implemented in the locally and circumstantially situated. Designing for the Power to Act Together of actors involved in a cross-functional and transactional collective means considering the possible modes of existence of this collective activity in context. Our research consisted in identifying the bases of these actors' Power to Act Together by highlighting the generic subjective instruments (Rabardel, 1995) that the actors built and mobilised in order to cooperate in a cross-functional manner.

\subsection{Understanding the bases of the Power to Act Together : a phenomenological ontology}

Following on from Theureau (2004, 2006, 2009, 2015), we place ourselves in a phenomenological ontology that is based on three hypotheses :

- the hypothesis for autonomous living systems, known as the general theory of autopoiesis, formulated by Maturana \& Varela $(1980,1987)$. According to this hypothesis, an actor - like any living system - constitutes an autonomous system, i.e. at each instant he/she constructs his/her activity as an interaction with his/her situation. This characteristic of autonomy signifies that interaction between the actor and his/her environment is asymmetrical, in the sense that at each instant the actor only interacts with the environmental characteristics that are pertinent for him/her - or for his/her internal dynamic - and consists of a dynamic of his/her structural coupling with said environment ;

- the hypothesis of pre-reflective self-consciousness which inspired Sartre's philosophical work (1943, 1936/1972). Pre-reflective self-consciousness constitutes a surface effect of these asymmetrical interactions between the actor and his/her environment and accompanies all human activities ;

- a third ontological hypothesis extends the first two hypotheses to collective activity, via an additional reference to Sartre (1943) in relation to a collective understood as a "detotalised totality". According to this third ontological hypothesis, "the concatenation of individual-social activities constitutes a collective activity that is constantly decollectivized by individual actors" (Sève \& al, 2012).

This incorporation within a phenomenological ontology leads us to consider, from a structural standpoint, the asymmetry of the relationships between actors and their environments, and to conceptualize collective activity as an articulation of individual activities. It is neither a subjectivist ontology which isolates the individual and considers collective activity to be the sum of individual activities, nor a collectivist ontology that excludes the individual; it is an ontology which considers relationships between the individual and his/her environment (including other actors) from a structural standpoint. This phenomenological ontology has an epistemological consequence : the primacy accorded to the actor's point of view. Consideration of the asymmetrical nature of Man's relationship with his environment involves seeing things from his point of view in order to understand his activity. The two approaches that are combined within the framework of this research - the instrumental approach (Folcher \& Rabardel, 2004a, 2004b; Rabardel, 1995, 2005a, 2005b; Rabardel \& Béguin, 2005; Rabardel, Folcher \& Béguin, 2002 ) and the course of action approach (Theureau, 2004, 2006, 2009; Theureau \& 
Jeffroy, 1994) - are "intrinsic" approaches (Daniellou \& Rabardel, 2005; Rabardel \& Béguin, 2005) to human activity, i.e. they attempt "to apprehend reality from the same angle as the subject, and to understand the activity generating mechanism on these grounds"(Rabardel \& Béguin, ibid, p. 431). This is why the understanding of the foundations of the Power to Act Together was achieved on the basis of an analysis of the individual-social activity (Theureau, 2004, 2006) of actors engaged in a cross-functional and transactional collective activity. Use of the individual-social point of view to approach the collective dimensions of human activity was the result of our ontological and epistemological choices.

\section{Analysing the collective processing of customer requests}

\subsection{Different types of request}

Our study concerns EDF's Service Relationships Centres (SRC). These are call centres which take calls from private customers wishing to make requests : enter into a contract, ask for information about a bill, request a payment plan, etc. EDF has 68 SRC spread over 8 regions, each of which deals with requests independently of customer location ${ }^{2}$.

We focused our analysis on the activity of customer service advisors, responsible for dealing with all types of customer requests. They are involved in the front-office activity of taking incoming calls from customers, and in the back-office business of dealing with mail received from customers, resolving anomalies reported by the information system, processing requests temporarily placed in a queue (by themselves or by others) and dealing with oral requests received from customers during incoming calls. These various front and back-office activities are subject to performance-related remuneration. Our examination of customer requests while we gathered data allowed us to categorise these requests.

Figure 1 - Categorization of requests formulated by phone/letters

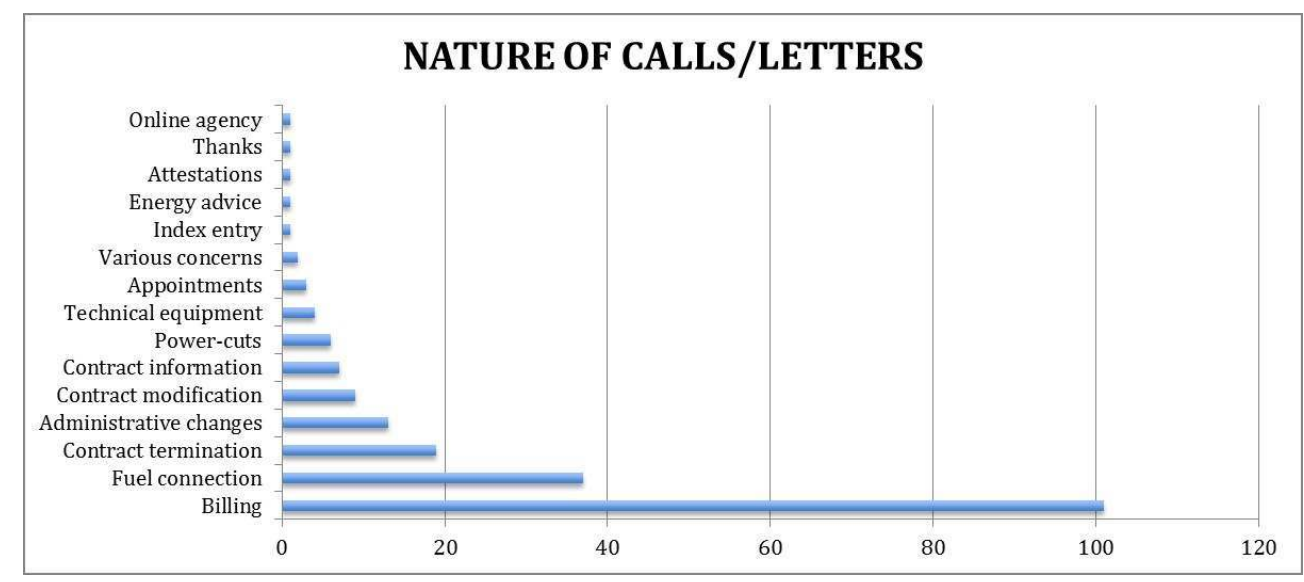

Figure 1 show the distribution among these various categories, based on all requests processed by customer service advisors during the period we collected data. The biggest category is that of billing. One example of this might be a customer who calls because he has received the same payment plan as the previous year, and wishes to know if this is normal. Or it might be a customer who does not understand his/her bill and who is asking 
for clarification, or someone whose direct debit was refused and who wishes to pay their bill in order to rectify the situation. The vast majority of these requests can be immediately processed by customer service advisors who provide customers with the information they need and process their payments. This is not the case for the second biggest category of requests, that of requesting connection ${ }^{3}$. This relates to people wishing to conclude electricity or electricity/gas contracts with EDF. These requests do not become effective immediately; the customer service advisors take the requests into consideration and create the contract, but for it to come into effect, other steps and skills are intrinsically involved.

Thus above and beyond categorisation according to type, requests can be categorised in terms of whether or not they may be processed in one go ("one-shot" requests) or over several stages. One-shot requests are processed in one go, by a single actor, and with an overlap between the end of request processing and the end of the process to deal with the customer's call/letter. For example, in the case of a request for bill clarification, the customer service advisor examines the customer's account and explains what the amount of the bill relates to. When the customer hangs up, his/her request is processed. Requests that intrinsically need to be processed in several steps are characterised by a process that involves the intersection of different stages and several different actors, whose respective contributions are spread over time and space and without any overlap between the end of the request process and the end of the process to deal with the customer's call/letter. When the customer hangs up, his/her request is still "ongoing" and additional contributions from other actors, elsewhere and at a later time, are required for the request to be effectively processed.

In order for requests which must intrinsically be processed in several steps to be dealt with from A to $\mathrm{Z}$, the various actors involved must cooperate in a cross-functional manner. Each actor deals in turn with one part of the request, until the latter has been fully processed. It is therefore within the framework of this type of request that crossfunctional and transactional collective activity must take place in order for the request to be effectively and efficiently processed.

\subsection{Processing requests for dual-fuel connections}

Requests for dual-fuel connection (electricity and gas) fall within this category of request, always requiring at least three steps in order to be fully processed, assuming that everything runs smoothly - i.e. not counting additional stages resulting from deferred processing or from an anomaly. 
Figure 2 - The constituent stages of processing requests for dual-fuel connection

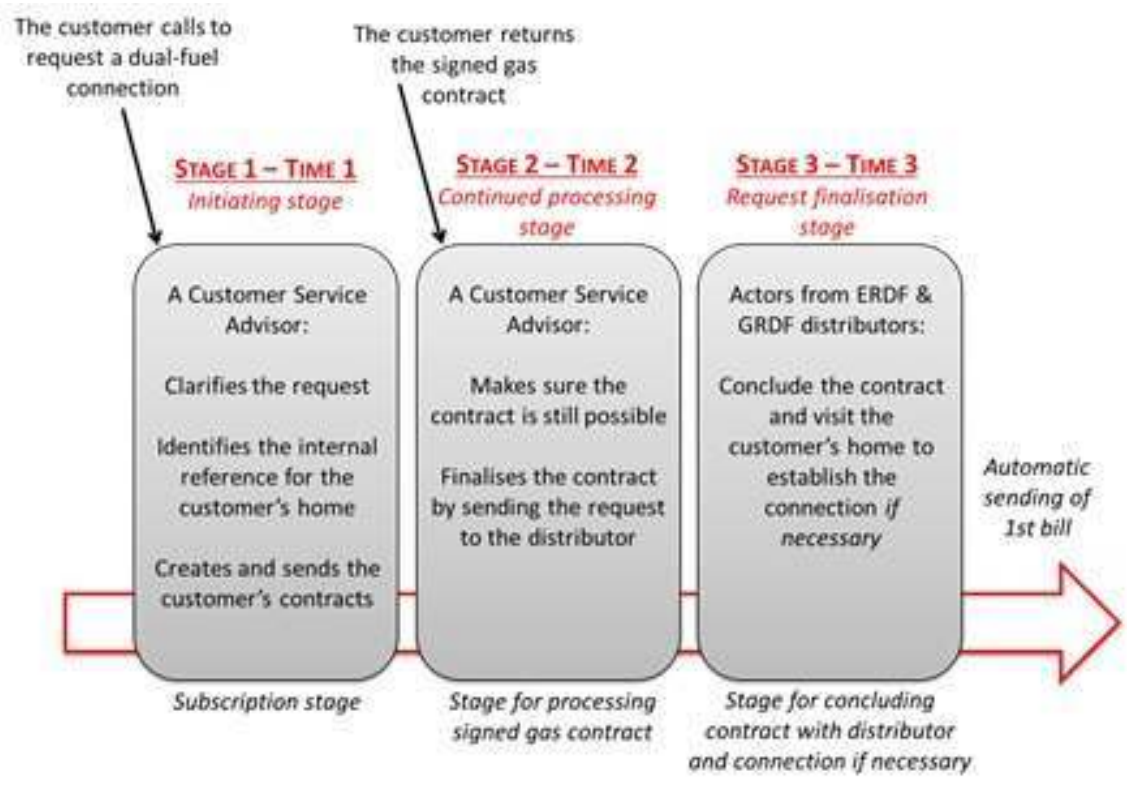

Figure 2 shows the stages involved in processing this type of request. Step 1 consists in taking the customer's request into consideration, clarifying it, creating the contracts and sending them to the customer so that he/she can return a signed copy. Once the customer has returned the signed gas contract, step 2 involves ensuring that the contract can be concluded and finalising it by passing the request on to the distributors so that they can make the necessary arrangements. Finally, step 3 consists in visiting the customer in order to establish the connection. Automatic sending of the first bill represents the end of the dual-fuel connection process. The customer service advisor in charge of a gas contract signed by a customer within the framework of a dual-fuel agreement (step 2) is thus part of a request already initiated by another advisor who created the contract, and which will continue beyond his/her own contribution when the distributors visit the customer. In other words, he/she is involved in processing a request that has a past and a future. Along with all of the other actors who have contributed and who will intervene in the processing at a later time, he/she is engaged in a crossfunctional and transactional collective activity.

\subsection{Data collection methodology}

From a methodological standpoint, the purpose of collecting data is therefore to be able to document the pre-reflective self-consciousness of the actors, i.e. what is "demonstrable, tellable, commentable at all times" without ruining the ongoing activity and thus breaking the dynamic of the course of action. The data collection methodology which makes this possible, as explained by Theureau $(2004,2006)$, consists in combining continuous observation and recording of the actors, provoked verbalisation by the actors in context and self-confrontation verbalisations. Our data gathering thus consisted in making continuous audio-video recordings of the activity of customer service advisors engaged in processing the various stages that make up requests for dual-fuel connection. We sat next to the customer service advisors, camera focused on their computer screens, and we took notes on the way their activity progressed and on the verbalisations of the customers 
(monitored calls). Immediately after the customer service advisors had completed the step, we talked to them about what they had just done, in an interview called "case postprocessing", which served the same purpose as the self-confrontation interviews (Theureau, 2004, 2006), i.e. expression of the actor's pre-reflective self-consciousness. The specificity of the collective activity considered within the framework of this work led us to add a second objective to these interviews : to talk to the actors about the before and after of their contribution, so that we could more broadly locate their contribution within the continuity of the request processing. Indeed, one of the intrinsic constraints of our study was that it was impossible to grasp $\mathrm{A}$ to $\mathrm{Z}$ processing of a single specific request from a single specific customer. It is in fact impossible to know when the customer will return their contract, the moment when said contract will be digitized by the actor concerned or at which SRC the digitized contract will be received and sent to a customer service advisor for processing. To offset this constraint, we gave these interviews a second role : in addition to allowing access to the actors' pre-reflective self-consciousness when processing the current step, we used them to talk to the actors about the before and after of their individual contributions. This allowed us to more broadly locate their contribution within the continuity of processing the request for dual-fuel connection.

In total, we collected 95 hours of audio-video recordings of 24 customer service advisors and of 2 of their line managers.

\subsection{From the individual to the collective, from the Power to Act to the Power to Act Together}

Regarding the analysis of these data and regarding the conceptualisation of collective activity that results from our ontological and epistemological choices, the aim was to understand individual activity and collective activity in one single movement. This meant that we had to see the individual point of view of every actor involved in this collective activity - a point of view that we might qualify as individual-social in the sense that it opens onto the activity of the other actors, which is taken into account when taking action. More specifically, we carefully analysed the individual-social activity of each actor and looked at the extent to which said activity was structured by a collective activity of a cross-functional and transactional nature. The starting point for our analyses was therefore to create an analysis graph which modelled the step-by-step construction of the individual-social activity of each customer service advisor, based on the identification of the various concerns ${ }^{4}$ structuring the activity.

Let us take the example of a customer service advisor processing a subscription to a contract (the first step in the request for connection process). Having identified the reference for the customer's home, enabling him/her to create the contract (the point of delivery), the advisor realises that the customer does not have all the information on the home which is required to create said contract. The advisor therefore prepares to end the conversation, but before doing so, he/she begins :

- a sequence ${ }^{5}$ during which he/she explains the process which will take place when the customer calls back: this involves telling the customer what information they will need when they call back in order for the customer service advisor in question to be able to rapidly identify them, giving them the various reference numbers they will need when they call back, and answering any questions the customer might have concerning documents they will need when they call ; 
- a sequence during which the advisor creates a "contact", i.e. a computer object that explains the nature of the call and lists any comments.

The preoccupations that form the basis of these sequences are :

- "reaching one's performance objectives in relation to this request for connection": the creation of the computer object ("contact") is counted as part of the objective of tracking the requests processed;

- "intersecting one's activity with that of the other actors involved in processing the request" : by informing the customer of the process which will take place when he/she calls back and by giving him/her the relevant reference numbers, the advisor lays the ground for the next person to talk to the customer on the phone when he/she calls back with all of the required information. So whilst the computer object ("contact") is created in order to reach these performance objectives, the fact of entering a comment is not based on the same concern. By entering a comment, the advisor is laying the ground for later processing of the request by whoever has the customer on the phone when he/she calls back. Figure 3 illustrates this concern to "intersect one's activity with that of the other actors involved in processing the request" as it relates to the fact of entering a comment into the "contact".

Figure 3 - Illustration of the preoccupation to "intersect one's own activity with that of the other actors involved in processing the request"

"The fact of entering a contact [the comment into the contact], the person who takes up the file the following day, with this reference number, will see the contact and the point of delivery I have entered. Which means they won thave to do any searching"

Using different modelling of customer service advisors' unique individual-social activity, we were able to access :

- the unique and generic aspects of the advisors' activity : comparison of all unique models of the advisors' individual-social activity allowed us to shift to a higher level of generality and to identify the typical preoccupations found within each modelling. For example, the preoccupation "to intersect one's activity with that of other actors" can be found in the activity of all customer service advisors involved in processing part of the request for dualfuel connection ;

- the generic instruments constructed by the actors, taken to be Capacities to Act: examination of the artefactual resources systematically mobilised to serve a typical concern allowed us to identify the generic instruments (Rabardel, 1995) that the actors constructed to serve their activity, i.e. their Capacities to Act (Rabardel, 2005a, 2005b) ;

- the individual and collective aspects of customer service advisor activity : the modelling of all of the preoccupations that structure the actors' individual-social activity demonstrates that these preoccupations might relate either to their individual activity or else to a collective activity. For example, the preoccupation "to reach one's performance objectives" relates to individual activity, whereas the preoccupation "to intersect one's activity with that of the other actors" is an example of individual activity being structured by a collective activity of a cross-functional and transactional nature. In highlighting the generic instruments constructed to serve this typical preoccupation which tends towards a crossfunctional and transactional collective activity, we were able to shift from documenting the Capacity to Act to that of the Capacity to Act Together ; 
- obstacles to the mobilisation of these Capacities to Act Together: using knowledge of the actors' Capacities to Act Together, i.e. of the generic instruments they had constructed to serve cross-functional and transactional collective activity, we were able to identify the circumstances that made their mobilisation possible, more complicated or impossible. These elements helped us to identify the bases of the Power to Act Together. each advisor's individual-social activity to move towards identification of the various aspects of this activity, including its collective dimension. At the same time, recourse to a phenomenology of human activity allowed us to shift from the Power to Act to the Power to Act Together.

\subsection{Customers : actors in the processing of their requests}

The processing of a request for dual-fuel connection is constructed both within the company, through the cross-functional interactions that it implies between actors, and with the customer who has made the request and who plays an active role in its processing. Until now, ergonomic studies in the field of service relationships have essentially focused on the analysis of synchronous interactions between customers and the professional actors involved in processing their requests (Cerf, Valléry \& Boucheix, 2004), thus placing the emphasis on the "transactional" aspect of collective activity. We chose to focus on its "cross-functional" dimension, based on the advisors' point of view, so as to understand the coordination mechanisms they implement in order to cooperate with the other actors engaged in processing the request for dual-fuel connection. This choice resulted in analyses where the customer is present, but seen from the customer service advisors' point of view. This might create the impression that it constitutes a residual element of our work, or even that it has been forgotten. This is not the case, but according primacy to the actor's point of view would have meant intersecting our analysis of this collective activity from the advisors' point of view with an analysis carried out from the customers' point of view. This was not done as part of this study but within the framework of the continuing "Engineering for the service relationship" research programme at EDF R\&D, of which this study is a part.

\section{Cooperative transitional instruments serving the continuity of the collective processing of customer requests}

\subsection{Capacities to Act Together : between inquiring and archiving}

In order to cooperate within the framework of a cross-functional and transactional collective activity, at every stage customer service advisors articulate : the reconstruction of previous aspects of request processing, current stage processing and anticipation of the next stage. Cooperation within this type of collective activity thus means articulating the past, present and future of the request at every stage (fig. 4). 
Figure 4 - Cooperating within a cross-functional and transactional collective activity : connecting the past, present and future at every stage

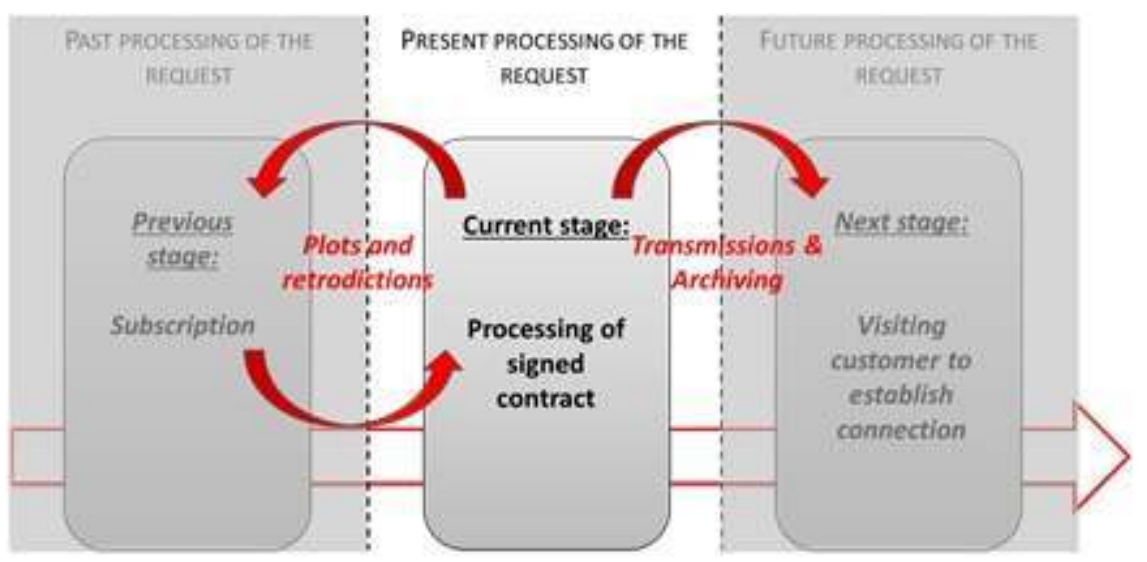

Customer service advisors who are processing a request for dual-fuel connection need to understand what has occurred at any given time during the processing. To achieve this, they must look at the file and be able to reconstruct the course of events leading up to and explaining the current situation. They therefore undertake an intense phase of interpretation: it is a case of "researching, consulting, checking, hypothesising, specifying..." Just like historians, customer service advisors have to unravel the "plot" (Veyne, 1971), which will vary depending on the processing stage. For example, a customer service advisor dealing with a "signed gas contract" (stage 2) must answer the question "is the contract still possible ?" before becoming involved in the stage for which he/she is responsible. To this end, he/she will look at the various tools at his/her disposal to find details which will make it possible to reconstruct the request history from a contract creation standpoint through to time t. Similarly, a customer service advisor who has to deal with an additional stage that was not planned and that results from an anomaly has to answer the question "What caused this request to become an anomaly ?" in order to understand what needs to be done to complete said stage. He/she thus begins an inquiry process to look for and select the elements that will make it possible to reconstruct the history of the request through to time $t$, thus explaining its current status. The following extract (fig. 5) illustrates this inquiry process, the aim of which is to answer the question "What caused this request to become an anomaly?". The section in bold shows that, like historians, customer service advisors have to perform "retrodictions" (Veyne, 1971), i.e. make reasonable inferences about what might have happened, in order to make up for patchy sources and fill in gaps (Veyne, ibid, p. 194). 
Figure 5 - Extract from a protocol concerning the "What caused this request to become an anomaly ?" plot

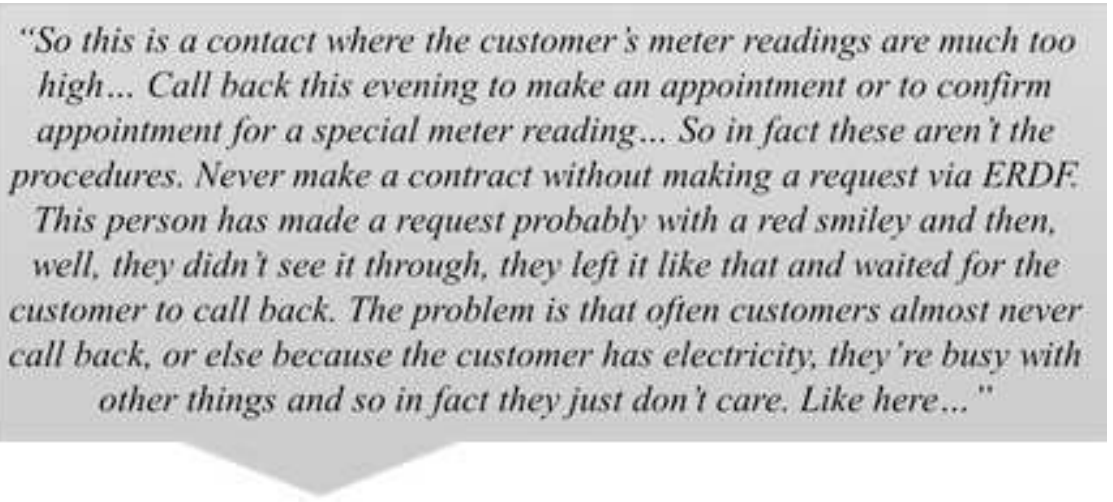

To unravel these plots, which characterise takeover in a cross-functional and transactional collective activity, customer service advisors have built instruments based on their professional experiences and at times of genesis. These instruments are their Capacities to Act and these Capacities to Act, which are Capacities of Inquiry, articulate three instruments ${ }^{6}$ :

- an instrument for being aware of time $t$ : it allows one to rapidly see the request status at time $t$, depending on the stage and thus on the plot in question. For the advisor, this means consulting, looking for and accessing different areas of the information system and/or questioning the customer when this is possible. The artefactual resources mobilised within this instrument are made up of the overviews (fig. 6) - at EDF and at the distributors relating to the customer or home in question and of the various lists (fig. 6) of contracts concerning a customer, of contracts concerning a home and of reasons for contact with a customer ;

Figure 6 - Illustration of overviews (on the left) and lists (on the right), artefactual resources constituent of the instrument for 'understanding at a time $t^{\prime}$ )

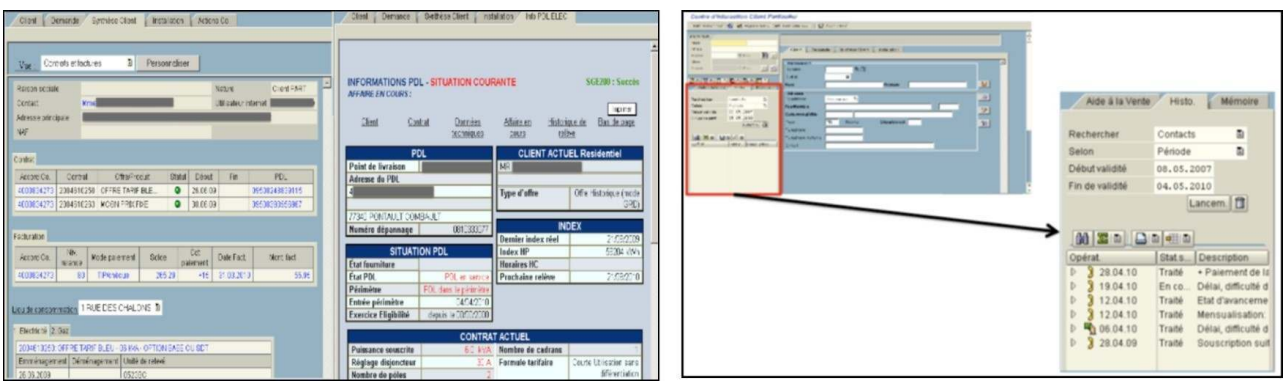

- an instrument for historical overview : this restores the status of a request at time $t$ of its history ; in other words it reconstructs the course of events and the actions of other actors who intervened upstream. For the advisor, this means consulting, looking for and accessing different areas of the information system and/or questioning the customer when this is possible. The artefactual resources mobilised within this instrument are made up of the comments (fig. 7) left in various parts of the information system by previous actors in the request process ;

- an instrument for finding historical information : this instrument makes it possible to find a specific piece of information relating to previous events and which is required in order for the processing to continue. As with the other two instruments making up the Capacities of 
Inquiry, this implies advisors looking for and accessing various areas of the information system and/or questioning the customer when this is possible. The artefactual resources mobilised within this instrument are made up of the comments (fig. 7) left in various parts of the information system by previous actors in the request process.

Figure 7 - Comments - an artefactual resource constituent of the 'historical overview' instrument and of the 'searching for a historical information' instrument

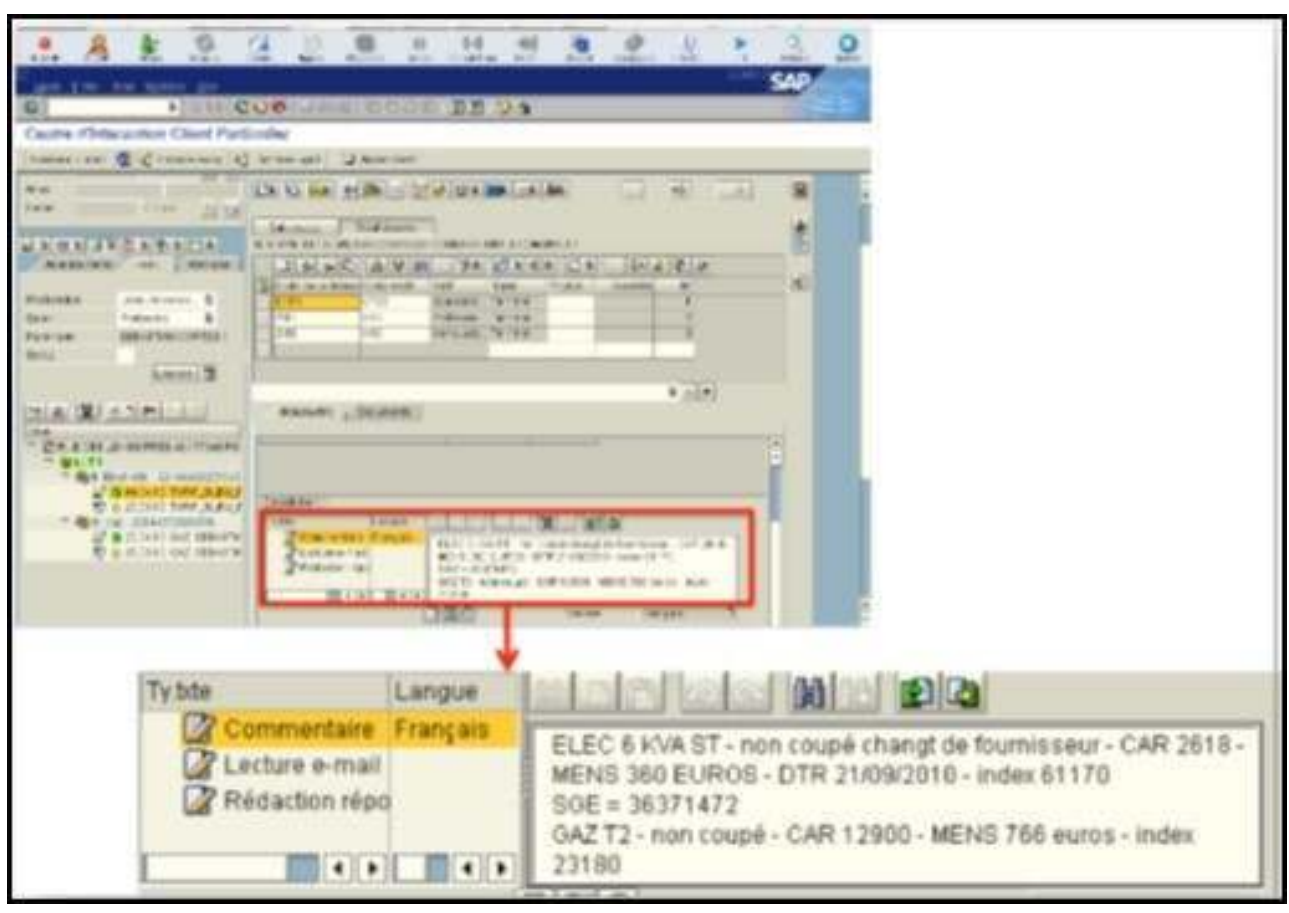

After unravelling the plot which allows them to take over and do whatever is required to process the current stage, customer service advisors prepare the ground for later processing by someone else. To achieve this they have capacities for transmission and archiving. The distinction between transmission and archiving depends on the knowledge that the advisor dealing with the current stage possesses in relation to the needs of future actors. If he/she has identified the next function in the process and knows what is needed for that stage to be processed, he/she will directly transmit the elements in question, knowing them to be pertinent to subsequent processing. If he/she has not identified the next function or does not know what that function requires, the advisor will archive the elements relating to his/her own activity and which he/she feels will be useful at a later date. The instruments that make it possible to transmit and archive to aid other actors in the request process constitute Capacities for Transmission and Archiving and articulate two instruments :

- an instrument for sharing elements from one's own situated experience : this instrument allows advisors to make details of their own activity, that they feel to be useful, available to people who will be involved at a later stage of the request process. This means selecting, copy-pasting and writing comments aimed at those who will subsequently take over. The artefactual resources mobilised in this instrument are constituted by zones of the information system in which one can write free-form comments ${ }^{7}$, or else by the customer if these zones are not available.

- an instrument for facilitating another person's effective takeover of the request : this allows advisors to integrate elements resulting from their here-and-now activity into the 
information system in such a way that they are immediately viewable and taken into account by every actor involved in processing the request. Advisors must select, copy-paste and write comments and also retype certain zones. The resources are made up of the various fields of the information system and will immediately viewable by the next actors in line. Capacities to Act Together that allow customer service advisors to work together to deal with customers' requests. These Capacities to Act Together are Cooperative Transitional Instruments (Poret, 2015). They are "transitional" (Bationo-Tillon, 2006; Bationo-Tillon, Folcher \& Rabardel, 2010) because they transit from one stage of request processing to another, and "cooperative" (Poret, 2015) because they are mobilised in a distributive fashion between the different actors of the cross-functional and transactional collective.

\subsection{Temporal continuity instruments at the heart of organisations}

These cooperative transitional instruments serve to articulate Past-Present-Future at every stage, because they allow the actor processing the current stage of the request to reconstruct past dimensions through the use of plotting, and to anticipate future processing via transmission/archiving. This means that they make it possible to presentify a request's past and future for each actor involved in processing a given stage of the request. If we set aside this "by stage" standpoint, broaden our focus and take an overall view of request processing, these instruments make it possible to transit between the future processing envisaged by Actor 1 at time $t$ and the past processing envisaged by Actor 2 at $t+1$ (fig. 8). In this way they are temporal continuity instruments at the heart of organisations.

Figure 8 - Cooperative Transitional Instruments, instruments of temporal continuity at the heart of organisations

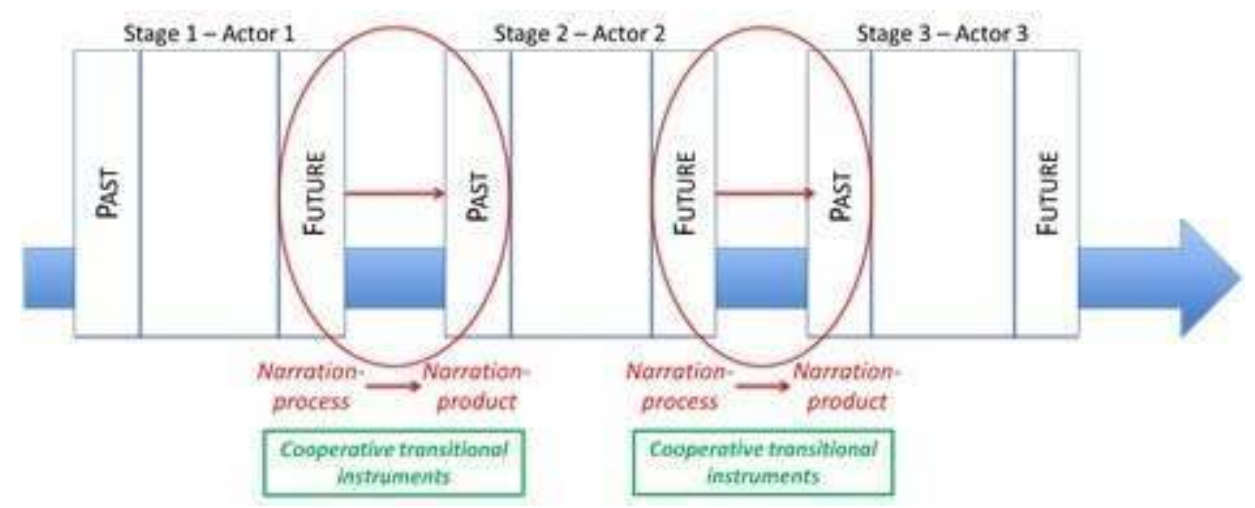

They allow the transition between step 1 at time $t$ and step 2 at $t+1$, maintaining a certain level of continuity. Unlike the transitional instruments highlighted by Bationo-Tillon (2006) in relation to individual activity, this continuity cannot be a continuity of experience because the actor intervening at stage 1 at time $t$ and the actor intervening at stage 2 at $t+1$ are not one and the same. In other words, these instruments make it possible to maintain a certain continuity when processing the request, despite the discontinuity of experience between the stages. This discontinuity of experience is what prevents the actors from referring to their own personal memory. It is the reason why, like historians, they instigate a historical search, the objective of which is to reconstruct past dimensions of the request processing. 
Examination of the artefactual resources making up the Capacities to Act Together shows that the narration is structural. In order to take over the request processing, customer service advisors plot the activity of previous actors. The mobilised and plotted material is made up of the comments left by previous actors. In other words, the material used to unravel the plots is comprised of the products of the narration of previous actors "narrations-products" (Giroux \& Marroquin, 2005). By plotting this material, the advisors obtain a plausible account of what has happened during the request process up until now, and are thus able to do what is needed to deal with the stage for which they are responsible. In order to prepare for a later takeover of the request process, they in turn undertake a "narration-process" (Giroux \& Marroquin, ibid) whereby they leave comments for later actors, in relation to their here-and-now activity.

Finally, cooperative transitional instruments make it possible to investigate and transmit/archive by going beyond the standard organisational boundaries. In order to unravel the plot, thus allowing them to take over processing of the request, customer service advisors need information - the traces left by actors within their own company and the traces left by the distributor's actors in relation to the ongoing request - in order to be able to integrate these elements into their historical reconstruction and into the plausible account of what took place prior to their own intervention. So the boundaries of these instruments do not correspond to the boundaries of the various artefacts proposed; instead they borrow from different artefacts relating to the different entities involved in the process.

\section{Designing for the Power to Act Together : the continuity criterion for technical-organisational design}

\subsection{Presentation of the continuity criterion}

43 Based on the understanding of the foundations of the Power to Act Together and in order to firmly entrench cross-functionality within organisations, we suggest a criterion for technical-organisational design. Because the practical effectiveness that is sought after through the implementation of this criterion is made up of a requirement for continuity in the processing of the request, based on a continuity of cross-functional and transactional collective activity, we have labelled this a "continuity criterion" (Poret, 2015). In proposing this generalizable design criterion, we wish to go beyond the stage of local adjustments specific to a given technical-organisational environment, in order to drive a movement of durable transformation of technical-organisational devices in line with a cross-functional logic.

The first requirement for implementing this criterion is that of identifying all of the actors and all of the planned and unplanned stages which need to be articulated in order to reach the final objective of the process - that of providing a customer with a service or product. This identification must both intra- and inter-organisationally integrate the actors and stages and must take place at an entry point through the individual, real and situated activity of the actors of the cross-functional and transactional collective. It is not a case of reviewing all of the official stages that constitute a process, but of immersing oneself in the process at any given stage in order to reconstruct it using elements of the individual, collective, real and situated activity of the actor in charge of the stage in question. During our analyses we were confronted with configurations where the actors' 
Power to Act Together was impacted because this identification had not been carried out. This is the case, for example, when a customer wishes to have information concerning the processing of his request by a service provider with whom the customer service advisor has no common space within the information system. It is then very difficult for the advisor to recover the details needed to unravel the historical plot that is characteristic of takeover in a cross-functional and transactional collective activity. This complicates his/her work and may also have a negative impact on customer satisfaction.

Cooperating in a manner transversal to the organisation means articulating Past-PresentFuture at every stage. The cooperative transitional instruments which serve this collective activity thus make it possible to presentify the past and the future within the framework of the current stage. The two remaining requirements for implementing the continuity criterion relate to these aspects :

- the second requirement consists in designing with a view to presentifying the past, for memory. Taking over in a cross-functional and transactional collective activity involves unravelling historical plots which vary depending on the stage at which one intervenes in this collective activity. Designing for the Power to Act Together consists in helping to unravel these plots by presentifying elements from the past, or via a temporal regression of events up to time $t$, so that the actor involved in processing the current stage knows exactly what has to be done when taking over. It is a case of proposing memory supports so that takeover is possible despite the fact that previous stages were not processed by the actor involved in the current stage. These collective memory supports must make it possible to effectively engage in the resolution of plots, by supporting the activity of historical inquiry implemented for this purpose by the actors of the cross-functional and transactional collective. The purpose of this presentification of the past is to make a story immediately visible : that of the different contributions leading to the process's status at time $t$, and on the basis of which one has to construct one's own contribution. This presentification of the past is also useful for the customer who needs to be able "to monitor and manage the evolution of his/her request, to have a better understanding of how the company's professions are organised [and] to make his/her involvement in the processing of the request more effective" (Motté \& Haradji, 2010, p. 27).

- the third requirement is that of designing for the presentification of the future, for expectation. In a cross-functional and transactional collective activity, preparing for the next stage means transmitting and archiving elements of one's own activity for the actors who will be involved at a later time. Designing for the Power to Act Together means facilitating this transmission and archiving of elements which whilst not directly pertinent for oneself at time $t$, may so be for future actors at a later date and in other places. It is a case, here and now, of anticipating the future of the cross-functional and transactional collective activity, i.e. of anticipating the needs of those who will be involved in this collective activity elsewhere and at a later date. The main proposition we are making in order to make the presentification of the future possible, is that of thinking about the integration of all actors of the cross-functional and transactional collective into common areas of the information system. The debate on practices discussed in the second part of this article plays a vital role in this respect, because the efficient transmission and addressing of elements of one's activity to those who will intervene at a later date of the request process means knowing their needs and thus being aware of the interdependencies between one's own contribution and those of future actors in the context of a cross-functional and transactional collective activity. 


\subsection{Designing an aid for the continuity of request processing : the interactive graph for monitoring request processing}

This criterion was mobilised in two of EDF's operational projects : a project to design an interactive graph for monitoring the request process, the idea being that the graph will be displayed as soon as a customer service advisor opens a client file, thus allowing him/ her to instantly see the progress report; and a project to model a process of the organisation using an understanding of cross-functional and transactional collective activity. We will now explain in greater detail how the continuity criterion allowed us to structure the first project.

The interactive graph for monitoring request processing is an innovation created by ergonomics researchers at EDF's R\&D department as part of their "Engineering for the service relationship" research programme, with a view to helping with cross-functional and transactional collective activity. Using a cross-functional and transactional collective activity modelling, and working with computer engineers, we discussed design principles and came up with a model for this graph. It has several characteristics (Motté, 2012) :

- it makes visible the collective construction of request processing by each actor involved (various EDF actors, the customer, actors at distribution companies);

- it is based on IT tools and on feedback on significant elements of the processing carried out within these tools. It is therefore updated without any human activity being necessary, and hence without adding to the workload of each of the actors involved in the cross-functional and transactional collective activity ;

- in parallel, it offers EDF-side and customer-side views, allowing everyone to monitor the progress of the request and to act in consequence. The graph thus makes it possible to develop both the "cross-functional" aspect of the activity relating to cooperation between professionals in order to collectively build customer service, and also the "transactional" dimension of this collective activity in relation to the fact that the latter involves the customer, with whom the aim is to reach a "transaction" : the production of his/her service ;

- it provides fast and direct access to business applications. The graph is not just a joint representation of the request and its progress ; it is also a point of entry into existing tools.

By making visible a chronology of the events that have taken place during the processing of the request and which gradually construct the process, the graph makes it possible to presentify the past at every stage - a necessary requirement for the implementation of the continuity criterion. It is an aid for the historical inquiry activity characteristic of takeover in the cross-functional and transactional processing of a request. A customer service advisor who opens a customer file can immediately see the status of the request, along with a time course of the events that explain said status. Depending on the stage at which a customer service advisor becomes involved, this time course will focus on different aspects. Historical inquiry concerns different plots, depending on the stage at which the advisor becomes involved. The information taken into account to unravel these plots therefore differs from stage to stage and focuses on different aspects. For example, the plot in which an advisor responsible for processing a stage of the "signed gas contract" is involved is "Is the contract still possible?" and the information selected to answer this question focuses on contracting at EDF and at the distributor. The plot in which an advisor responsible for processing an anomaly stage is involved is different ("What caused this request to become an anomaly?") and the information selected to 
respond focuses on the history of the request at EDF and at the distributor. The history to be reconstructed in order to take over in a cross-functional and transactional collective activity will therefore vary, depending on the stages at which the customer service advisors become involved. We suggested display modes that differ from the graph, depending on the stage and plot concerned.

Figure 9 - Logic of the graph to unravel the "Is the contract still possible ?" plot

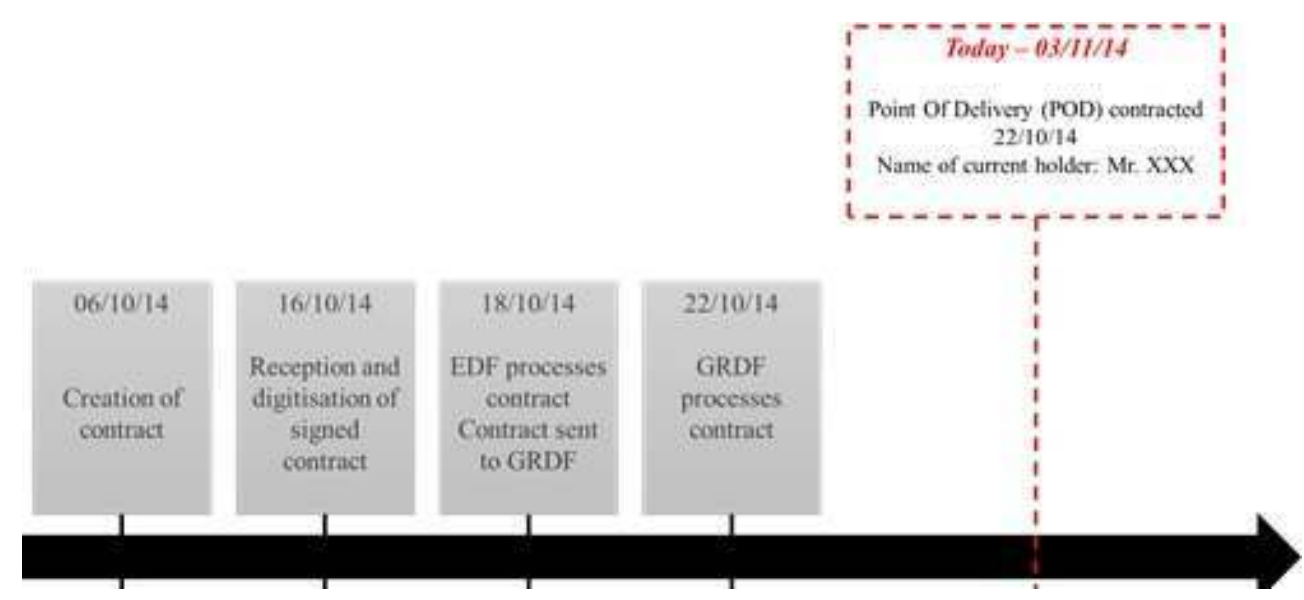

For example, figure 9 shows the logic of this graph for a customer service advisor involved in a stage of the signed gas contract process. For a given home, the graph displays elements relating to contract history with EDF and with the distributor, with a view to unravelling the "Is the contract still possible ?" plot. Here we are illustrating one way of presentifying the past in order to develop the "transversal" aspect of crossfunctional and transactional collective activity. This presentification of the past is also designed to develop its "transactional" dimension by allowing the customer to have such a graph at his/her disposal - through the display of various pieces of information - in order to see the status of his/her request. The graph could be available in his/her customer space, thus helping to strengthen Customer Relationship Management (CRM) via the internet.

\section{Conclusion and discussion}

This research was carried out in the context of transforming the organisations and professions of the service relationship at EDF, following the opening up of the energy market to competition. The aim was to understand the dynamic of cross-functional and transactional collective activity between actors of the same process who have to work together to achieve the final objective of the process - providing a service to the customer. Authors from the fields of ergonomics and management highlighted the importance of this collective activity and suggested devices for debating on practices in order to develop it. Yet this manner of designing for cross-functional and transactional collective activity is limited, because it focuses solely on the actors involved in the activity and ignores the technical and organisational environment in which it has to be able to operate. So if design for this type of collective activity does not take the "ActorEnvironment" relationship into consideration, the risk is that of it only being possible to construct the knowledge that is vital for cooperation, without being able to mobilise it in context. The risk is therefore that of simply allowing the construction of Capacities to Act 
Together without systematically considering the matter of their effective mobilisation in context : the Power to Act Together (Poret, 2015). We have demonstrated and described the resources of this Power to Act Together at the heart of a cross-functional and transactional collective activity - the cooperative transitional instruments (Poret, ibid) that make it possible to articulate Past-Present-Future at every stage and thus to cooperate within a collective activity that is temporally and spatially dispersed among several actors. Finally, we have suggested a criterion for the design of technicalorganisational systems which durably anchor cross-functionality at the heart of organisations by enabling the Power to Act Together - the continuity criterion - and we have illustrated its mobilisation within the framework of an operational project at EDF.

51 Engaging in a work of research implies betting on the nature of things (Theureau, 2002a, 2002b). So in order to understand the bases of the Power to Act Together, we chose to use an individual-social mesh analysis. This choice was based on ontological, epistemological and methodological considerations which, structurally speaking, take into account the asymmetry of the relationship between Man and his environment, thus according primacy to the actor's point of view when it comes to understanding his/her activity. This type of mesh analysis is not the unanimous choice of all authors interested in crossfunctional and transactional collective activity. For example, Lorino $(2009,2013)$ uses a dialogical mesh analysis that is collective from the outset, without first using an individual-social mesh analysis. We put forward several reasons why individual-social mesh analysis is cogent and pertinent to the study of cross-functional and transactional collective activity. Firstly, because only individual-social mesh analysis allows one to access the subjective instruments that actors construct to serve their activity and thus to engage in design without focusing solely on the actors. We argue that only this individual-social mesh analysis can make it possible to engage in the technical design that is essential for the existence of cross-functional and transactional collective activity within organisations. Furthermore, as our research shows, individual-social mesh analysis provides access to the activity's addressing phenomena. Indeed, at every processing stage, cooperation within the framework of a cross-functional and transactional collective activity consists in plotting the elements that have been provided by other actors, and, in turn, addressing elements for future plotting by actors who will be involved at a later date. To give primacy to the actor's point of view is thus to choose a path which makes it possible to reintegrate an actor isolated by a subjectivist ontology and excluded by a holistic ontology.

We believe that these two forms of mesh analysis - dialogical and individual-social - are complementary when it comes to understanding human activity, most particularly because they allow one to highlight two types of interdependent inquiry which take place at the heart of organisations: 1) an interprofessional inquiry which creates the preconditions for cross-functional and transactional cooperation in that it examines the needs of other actors in order to integrate them into one's own activity, and 2) a historical inquiry which makes it possible to take over and to cooperate within the framework of a cross-functional and transactional collective activity. They are also complementary with regard to design, with one of them proposing to design in order to construct the preconditions for collective activity and the other to design in a manner that allows it to exist in context, i.e. in a technical-organisational environment that fragments this activity. For all of these reasons, we believe that it is the articulation between these two mesh analyses and between their complementary contributions in 
terms of understanding human activity and design that will make it possible to durably anchor cross-functionality at the heart of organisations.

Given this necessity to anchor cross-functionality at the heart of organisations, some authors (Hammer, 1990; Hammer \& Champy, 1993) suggest Business Process Reengineering (BPR) to improve a company's performance. One of the principles of this reengineering (Hammer, 1990) is to make agents polyvalent, i.e. to ensure that a single agent deals with all stages of a process. One might therefore think that to process a request in different stages is to artificially segment it, thus making it more complicated, and that polyvalence is the way to anchor cross-functionality in organisations. The scope of our research would then be almost nil and the continuity criterion would be useless because it would suffice to ensure that agents were polyvalent for continuity to be effective. The need to allow a continuity of the collective activity between several persons would no longer be relevant because it would be replaced by the continuity of experience for a single person! Yet things are not that simple. Firstly, the fact that processing a request for dual-fuel connection involves different professions - those of the distributor and the marketer - automatically entails different stages. The specificities of the different professions therefore restrict this principle of process reengineering ; a customer service advisor's job is not to visit the customer's home to establish the connection - this is the distributor's role. Furthermore, the energy market contains a huge number of consumers; EDF has 25 million private customers in France $^{8}$ for example. Even if polyvalence were made possible for all stages of the request for dual-fuel connection, for all professionals, this mass market dimension means that it would be impossible for a single customer service advisor to provide an individualised follow-up for a single given customer and request. These two characteristics - different professionals and a mass market - are at the origin of the fact that the polyvalence of agents cannot be the unique solution for ensuring the continuity of customer requests and hence the company's performance in satisfying such requests. Moreover, EDF's customer service advisors are polyvalent. Being involved in both front and back-office activities, they have to deal with various stages of the same process. For example, regarding the processing of requests for dual-fuel connection, customer service advisors might deal with the subscription stage (stage 1) or the stage which processes the signed gas contract (stage 2) or any other additional stages that might be due to deferred processing or anomalies. This means that they might be responsible for different stages of a given process, as is proposed with process reengineering. Whilst they are responsible for dealing with different stages of a process, it is nevertheless impossible for them to process these stages for a single given request and a single given customer; so polyvalence does not mean personalised monitoring of a customer request for a single given customer and it is not therefore the key to continuity and cross-functionality in organisations.

54 Finally, this requirement of anchoring cross-functionality in organisations will certainly grow stronger in years to come. Generally speaking, organisational configurations that involve the creation of a cross-functional and transactional collective activity will continue to develop in all sorts of areas. This is the case for example in the field of medicine, where the need to ensure continuity of care between service providers from different professions will most certainly be of increasing importance given the economic context and the growing need for home care. In the energy sector, the deployment of information and communications technologies (ICT) on public electricity and gas networks will - through the management of data fed back by such technologies - make it 
possible to offer personalised services to customers. This "mass customization" (Roy \& Audet, 2002) is likely to complicate current processes, especially given the growing number of actors who will be integrated in order to provide such a service.

\section{BIBLIOGRAPHY}

Arnoud, J. (2013). Conception organisationnelle : pour des interventions capacitantes. Thèse de doctorat, Conservatoire National des Arts et Métiers, Paris.

Arnoud, J., \& Falzon, P. (2013). La co-analyse constructive des pratiques. In P. Falzon (Ed.), Ergonomie constructive (pp. 223-236). Paris : Presses Universitaires de France.

Arnoud, J., \& Falzon, P. (2014). Favoriser l'émergence d'un collectif transverse par la co-analyse constructive des pratiques. Le Travail Humain, 77 (2), 127-153.

Askenazy, P. (2005). Charge mentale au travail : les contributions d'une approche économique. In J. Furtos, \& C. Laval (Eds.), La santé mentale en actes (pp. 127-151). ERES, Études, recherches, actions en santé mentale en Europe.

Bationo Tillon, A. (2006). Pratiques des activités narratives instrumentées : Une analyse diachronique et structuro-fonctionnelle en amont de la conception. Université Paris 8 : Thèse de Doctorat en Ergonomie.

Bationo, A., Folcher, V., \& Rabardel, P. (2010). Les instruments transitionnels une proposition pour étudier la diachronie des activités narratives. Activités, 7(2), 63-83. http:// activites.revues.org/2437.

Bernard, S. (2005). Le temps de l'activité de la caissière entre logique productive et logique de service. Sociologie du travail, 47, 170-187.

Bidet, A., Boutet, M., \& Chave, F. (2013). Au-delà de l'intelligibilité mutuelle : l'activité collective comme transaction. Un apport du pragmatisme illustré par trois cas. Activités, 10(1), 172-191. http://activites.revues.org/632.

Boreham, N., Samurçay, R., \& Fischer, M. (2002). Work Process Knowledge. London : Routledge.

Buscatto, M. (2002). Les centres d'appels, usines modernes ? Les rationalisations paradoxales de la relation téléphonique. Sociologie du travail, 44, 99-117.

Calderon, J. (2006). Le travail face à la restructuration productive : le cas d'un centre d'appels. Formation emploi, 96, 11-24.

Cerf, M., Valléry, G., \& Boucheix, J.-M. (2004). Les activités de service : enjeux et développements. In P. Falzon (Ed.), Ergonomie (pp. 565-581). Paris : Presses Universitaires de France.

Cihuelo, J. (2010). Le cas d'un modèle hybride de centre d'appels. Entre rationalisation et réappropriation professionnelle. Réseaux, 164, 164-196.

Daniellou, F., \& Rabardel, P. (2005). Activity-oriented approaches to ergonomics: some traditions and communities. Theoretical Issues in Ergonomics Science, 6(5), 353-357. 
Defelix, C. (1999). Transversalité, contrôle et gestion des ressources humaines : un cas de pilotage à l'épreuve des processus. Finance Contrôle Stratégie, 2(2), 51-70.

Derujinsky-Laguecir, A., Kern, A., \& Lorino, P. (2011). Une approche instrumentale des indicateurs de performance. Management \& Avenir, 2(42), 111-132.

Detchessahar, M. (2003). L'avènement de l'entreprise communicationnelle. Revue française de gestion, 1(142), 65-84.

Dewey, J., \& Bentley, A. F. (1949). Knowing and the Known. Boston : The Beacon Press.

Du Tertre, C. (2013). Économie servicielle et travail : contribution théorique au développement «d'une économie de la coopération ». Travailler, 1(29), 29-64.

Flageul-Caroly, S. (2001). Régulations individuelles et collectives des situations critiques dans un secteur des services : le guichet de La Poste. Paris : Thèse, LEPC-EPHE.

Folcher, V., \& Rabardel, P. (2004a). Hommes, artefacts, activités : perspective instrumentale. In P. Falzon (Ed.), Ergonomie (pp. 251-268). Paris : Presses Universitaires de France.

Folcher, V., \& Rabardel, P. (2004b). Artifacts as design-for-use propositions for design-in-use activity. Invited conference to the symposium "Perception, Communication and Activity". International Congress of Psychology (ICP 2004), 7-13 Août 2004, China.

Giroux, N., \& Marroquin, L. (2005). L'approche narrative des organisations. Revue Française de Gestion, 6(159), 15-44.

Greenan, N., \& Mairesse, J. (2006). Les changements organisationnels, l'informatisation des entreprises et le travail des salariés. Un exercice de mesure à partir de données couplées entreprises/salariés. Revue économique, 57(6), 1137-1175.

Hammer, M. (1990). Reengineering Work: don't automate, obliterate. Harvard Business Review, 104-114.

Hammer, M., \& Champy, J. (1993). Le Reengineering (édition française). Paris : DUNOD.

Hochereau, F. (2004). L'évolution de la fonction commerciale à France Telecom (1978-1998) à travers son informatisation. In L. Deroche, \& G. Jeannot (Eds.), L'action publique au travail (pp. 17-24). Toulouse : Octarès Éditions.

Khoshafian, S., \& Buckiewicz, M. (1998). Groupware \& workflow. Paris : Masson.

Lasnier, G. (2007). Le lean-manufacturing (système de production à haute performance) dans les industries travaillant en juste-à-temps avec flux régulés par takt-time (rythme de la consommation du client). La Revue des Sciences de Gestion, 1(223), 99-107.

Lave, J., \& Wenger, E. (1991). Situated learning. Legitimate peripheral participation. Cambridge : Cambridge University Press.

Lorino, P. (2009). Concevoir l'activité collective conjointe : l'enquête dialogique. Étude de cas sur la sécurité dans l'industrie du bâtiment. Activités, 6(1), 87-110. http://activites.revues.org/2154.

Lorino, P. (2013). L'activité collective, processus organisant. Un processus discursif fondé sur le langage pragmatiste des habitudes. Activités, 10(1), 1-24. http://activites.revues.org/656.

Lorino, P., \& Peyrolle, J.-C. (2005). Démarche pragmatiste et mise en processus dans les situations de gestion. In R. Teulier, \& P. Lorino (Eds.), Entre connaissance et organisation : l'activité collective (pp. 220-229). Paris: La Découverte. 
Lorino, P., \& Tricard, B. (2012). The Bakhtinian Theory of Chronotope (Time-Space Frame) Applied to the Organizing Process. In M. Schultz, S. Maguire, A. Langley, \& H. Tsoukas (Eds.), Constructing identity in and around Organizations (pp. 201-234). Oxford: Oxford University Press.

Maturana, H., \& Varela, F. (1980). Autopoiesis and Cognition. Dordrecht : Reidel.

Maturana, H., \& Varela, F. (1987). The tree of knowledge. Boston/London : Shambala.

Motté, F. (2012). Le collectif transverse : un nouveau concept pour transformer l'activité. In Actes du 47ème Congrès International de la Société d'Ergonomie de Langue Française (SELF) (pp. 102-108).

Motté, F., \& Haradji, Y. (2010). Construire la relation de service en considérant l'activité humaine dans ses dimensions individuelles et collectives. In G. Vallery, M.-C. Le Port, \& M. Zouinar (Eds.), Ergonomie et conception de produit et de services médiatisés (pp. 11-35). Paris : Presses Universitaires de France.

Mourlon, S., \& Neyer, L. (2002). Tout ce que nous avons voulu savoir sur les ERP. Qu'attendre des Progiciels de Gestion Intégrés? Mémoire d'Ingénieurs Elèves - École des Mines de Paris.

Nascimento, A. (2009). Produire la santé, produire la sécurité. Développer une culture collective de sécurité en radiothérapie. Paris : Thèse de doctorat du Conservatoire National des Arts et Métiers (CNAM).

Petit, J. (2005). Organiser la continuité du service : Intervention sur l'organisation d'une Mutuelle de santé. Thèse pour l'obtention du grade de docteur en ergonomie de l'université Bordeaux 2.

Poret, C. (2015). Concevoir pour le Pouvoir d'Agir Ensemble d'un collectif transverse. Le cas de la relation de service dans le domaine commercial. Thèse de doctorat - Université Paris VIII.

Rabardel, P. (1995). Les Hommes et les technologies. Paris : Armand Colin.

Rabardel, P. (2005a). Instrument subjectif et développement du pouvoir d'agir. In P. Rabardel \& P. Pastré (Eds.), Modèles du sujet pour la conception. Dialectiques activités développement. Toulouse : Octarès Éditions.

Rabardel, P. (2005b). Instrument, activité et développement du pouvoir d'agir. In R. Teulier, \& P. Lorino (Eds.), Entre connaissance et organisation : l'activité collective (pp. 251-265). Paris: La Découverte.

Rabardel, P., \& Béguin, P. (2005). Instrument mediated activity: from subject development to anthropocentric design. Theoretical Issues in Ergonomics Science, 6(5), 429-461.

Rabardel, P., Folcher, V., \& Béguin, P. (2002). Les instruments pour l'action : une approche développementale. Communication à l'atelier de conjoncture de la Société Française de Psychologie (SFP), Octobre 2002, CNAM-Paris.

Roy, M., \& Audet, M. (2002). La transformation vers de nouvelles formes d'organisation plus flexibles : un cadre de référence. Gestion, 27(4), 43-49.

Sartre, J.-P. (1936/1972). La transcendance de l'ego. Essai d'une description phénoménologique. Paris : Vrin.

Sartre, J.-P. (1943). L’Être et le néant. Essai d'ontologie phénoménologique. Paris : Éditions Gallimard.

Segrestin, D. (2004). Les chantiers du manager. L'innovation en entreprise : où en sommes-nous? Comment piloter les changements et les maîtriser? Paris : Armand Colin. 
Sève, C., Theureau, J., Saury, J., \& Haradji, Y. (2012). Drôles d'endroits pour une rencontre : STAPS, Ergonomie et Cours d'Action. In M. Quidu (Ed.), Les sciences du sport en mouvement. Innovations et traditions théoriques en STAPS. Paris : L'Harmattan.

Tarondeau, J.-C. (2002). Le management des savoirs. Paris : PUF.

Theureau, J. (2002a). Cours d'expérience, cours d'action, cours d'interaction : essai de précision des objets théoriques de l'activité individuelle-sociale. 4e Journées Act'Ing "Objets théoriques, objets de conception, objets d'analyse et situations d'étude privilégiées", 6-7 juin, Nouan le Fuzelier.

Theureau, J. (2002b). Articulation collective des cours d'action : de l'inspiration Sartrienne à un programme de recherche. $4^{\mathrm{e}}$ Journées Act'Ing “Objets théoriques, objets de conception, objets d'analyse et situations d'étude privilégiées", 6-7 juin, Nouan le Fuzelier.

Theureau, J. (2004). Le cours d'action : méthode élémentaire. Toulouse : Octarès Éditions.

Theureau, J. (2006). Le cours d'action : méthode développée. Toulouse : Octarès Éditions.

Theureau, J. (2009). Le cours d'action : méthode réfléchie. Toulouse : Octarès Éditions.

Theureau, J. (2015). Le cours d'action. L'enaction \& l'expérience. Toulouse : Octarès Éditions.

Theureau, J., \& Jeffroy, F. (1994). Ergonomie des situations informatisées. La conception centrée sur le cours d'action de l'utilisateur. Toulouse : Octarès Éditions.

Trompette, P., \& Boissin, O. (2000). Entre les vivants et les morts : les pompes funèbres aux portes du marché. Sociologie du travail, 42, 483-504.

Ughetto, P. (2012). Le lean : pensée et impensé d'une activité sans relâchement. Activités, 9(2), 148-167. http://activites.revues.org/453

Veltz, P., \& Zarifian, P. (1994). Travail collectif et modèles d'organisation de la production. Le Travail Humain, 57(3), 239-249.

Veyne, P. (1971). Comment on écrit l'histoire. Paris : Éditions du Seuil.

Watiez, J.-C. (2002). Flexibilité et adaptation de l'organisation à l'environnement : la flexibilité en tant que réponse à l'asymétrie inter et intra entreprises. Finance Contrôle Stratégie, 5(1), 217-254.

Zarifian, P. (1995). Travail et communication. Paris : L'Harmattan.

\section{NOTES}

1. Here we use the standard meaning of the term "transactional", i.e. that the collective activity in question must lead to a value-creating transaction with the customer. We do not use it in the pragmatist sense defined by Dewey \& Bentley (1949), more recently taken up by Bidet, Boutet \& Chave (2013).

2. Characteristics from the time we collected the data ( $1^{\text {st }}$ semester 2010$)$

3. At national level, 3.2 million applications for connection are processed each year, whence the importance of looking at the collective cross-functional and transactional activity that is required to ensure that customers receive a high-quality service.

4. More accurately, it concerned a modelling of the history of the transformations of the system of openings (Theureau, 2006).

5. For a full description of these sequences (Theureau, 2004, 2006, 2009) using the Significant Elementary Units (SEU) that constitute them, see Poret (2015)

6. For a more complete description of these instruments, mixed entities made up of schemes and artefacts, see Poret (2015) 
7. Figure 7 illustrates just such a zone. The difference between its mobilisation within the framework of historical overview/historical information search instruments AND, within the framework of this instrument, of sharing aspects of one's situated experience, is that with regard to instruments relating to the history, the resource is the comment itself, and with regard to the instrument relating to the future, the resource is the blank zone containing no comment.

8. Press release dated $10^{\text {th }}$ February 2016 : "EDF number 1 for customer service in the "service" category.

\section{ABSTRACTS}

With regard to transformations of the economic environment and structural changes in companies which now conceptualize their performance on the basis of their cross-functional processes, it is essential to understand the efficiency levers that organisations employ to cope with customer requests. One of these levers is cross-functional cooperation between actors who are members of the same process, based on a new kind of collective activity : cross-functional and transactional collective activity (Motté \& Haradji, 2010 ; Poret, 2015). This collective activity involves actors who are members of a same process cooperating by crossing over the organisation's various boundaries. Taking an understanding of the modes of coordination which form the basis for cooperation between members of the same cross-functional process, this research highlights the existence of instruments (Cooperative Transitional Instruments (Poret, ibid)) that allow these actors to cross the organisation's typical boundaries in order to cooperate, and proposes a criteria for the IT and organisational system in order to durably anchor crossfunctionality and enable the Power to Act Together at the heart of organisations.

Dans un contexte de transformations de l'environnement économique et de changements structurels des entreprises qui doivent penser leur performance à partir de leurs processus transversaux, il est essentiel de comprendre les ressorts de l'efficacité des organisations pour répondre aux demandes de leurs clients. Un de ces ressorts est constitué par une coopération transverse entre les acteurs engagés dans un même processus, dans le cadre d'une activité collective d'un type nouveau: l'activité collective transverse et transactionnelle (Motté \& Haradji, 2010 ; Poret, 2015). Cette activité collective implique pour les acteurs du processus de coopérer de façon transverse à l'organisation. À partir de la compréhension des modes de coordination qui fondent la coopération des acteurs d'un processus transverse, cette recherche met en évidence l'existence d'instruments qui permettent à ces acteurs de dépasser les frontières classiques de l'organisation pour coopérer: les Instruments Transitionnels Coopératifs (Poret, ibid), et propose un critère pour la conception des systèmes technico-organisationnels afin d'ancrer durablement la transversalité et de permettre le Pouvoir d'Agir Ensemble au cœur des organisations. 
INDEX

Mots-clés: relation de service, activité collective transverse, pouvoir d'agir, approche instrumentale, cours d'action

Keywords: service relationship, cross-functional collective activity, Power to Act, instrumental approach, course of action

\section{AUTHORS}

CÉLINE PORET

Université Paris 8, EDF R\&D, poret_celine@yahoo.fr

\section{VIVIANE FOLCHER}

Université Paris 8, viviane.folcher@univ-paris8.fr

FLORENCE MOTTÉ

EDF R\&D, florence.motte@edf.fr

YVON HARADJI

EDF R\&D, yvon.haradji@edf.fr 